\title{
Involvement of Macrophage Migration Inhibitory Factor (MIF) in the Mechanism of Tumor Cell Growth
}

\author{
Norihiko Takahashi, ${ }^{1}$ Jun Nishihira, ${ }^{2}$ Yuji Sato, \\ Masao Kondo,' Hideaki Ogawa,' Takahiro Ohshima,' \\ Yoshie Une, ${ }^{1}$ and Satoru Todo ${ }^{1}$ \\ ${ }^{1}$ First Department of Surgery, Hokkaido University School of \\ Medicine, Sapporo, Japan \\ ${ }^{2}$ Central Research Institute, Hokkaido University School of Medicine, \\ Sapporo, Japan \\ Accepted October 12, 1998.
}

\begin{abstract}
Background: Macrophage migration inhibitory factor (MIF) was recently rediscovered as a cytokine, pituitary hormone, and glucocorticoid-induced immunomodulator. MIF is constitutively expressed in various cells and enhances production of inflammatory cytokines such as tumor necrosis factor- $\alpha$, interleukin- 1 , and interferon $\gamma$. Recently, it was reported that MIF mRNA was overexpressed in prostatic tumors, which suggests that MIF is a protein involved in tumor cell growth beyond inflammatory and immune responses.

Materials and Methods: We examined the expression of MIF in the murine colon carcinoma cell line colon 26 by Western and Northern blot analyses and immunohistochemistry. Next, we investigated the effects of transforming growth factor (TGF) $\beta$, basic fibroblast growth factor (b-FGF), and platelet-derived growth factor (PDGF) on the expression of MIF mRNA. Furthermore, we examined whether MIF is involved in tumor cell proliferation, using an MIF anti-sense plasmid transfection technique.
\end{abstract}

Results: We demonstrated that MIF protein and its mRNA were highly expressed in colon 26 cells, using Western and Northern blot analyses, respectively. By immunohistochemical analysis, we found that MIF was localized largely in the cytoplasm of the tumor cells. In response to TGF- $\beta$, b-FGF, and PDGF, MIF mRNA expression was significantly up-regulated. Following this, we transfected the cells with an anti-sense MIF plasmid, which revealed that this treatment induced significant suppression of cell proliferation.

Conclusion: Although MIF plays multifunctional roles in a broad spectrum of pathophysiological states, little has been done to investigate the role of this protein in association with tumor growth. The current results suggest the possibility that MIF induces tumor cell growth in concert with other growth factors, which encouraged us to investigate a novel approach for tumor therapy using an anti-MIF antibody and an MIF anti-sense plasmid transfection technique.

\section{Introduction}

Little progress has been made in the treatment of patients with advanced or metastatic colorectal

Address correspondence and reprint requests to: Dr. Jun Nishihira, Central Research Institute, Hokkaido University School of Medicine, Sapporo 060, Japan. Phone: +81-11706-6081; Fax: +81-11-706-7864; E-mail:

j_nisihi@med.hokudai.ac.jp cancers. Cytological examination of tumor cells to determine the potential for proliferation and metastasis is important for the prognosis and therapy of the patient. Colon cancer cells secrete and/or respond to several growth factors, including transforming growth factor (TGF) $\beta$, plateletderived growth factor (PDGF) and basic fibroblast growth factor (b-FGF), and express specific 
receptors for these proteins (1). These growth factors and their receptors play a pivotal role in regulating cellular proliferation and transformation. With regard to the histological characteristics of colorectal tumors, macrophages are frequently localized at the periphery of stromal tissues adjacent to the zones of metastatic tumor invasion, where they secrete a variety of growth factors and cytokines.

In the last few years, several reports, including ours, demonstrated that constitutive expression of macrophage migration inhibitory factor (MIF) was not limited to $\mathrm{T}$ cells. It is also expressed by macrophages and various organs, including brain, liver, and kidney (2-4). As for the biological functions, MIF was discovered to be a pituitary hormone, inflammatory cytokine, and glucocorticoid-induced immunoregulator (5). Other than these biological properties, it has been considered that MIF might also be involved in cell proliferation and differentiation, based on the following reports. MIF was predominantly localized in differentiating cells of the embryonic chicken lens (6), and specifically detected at the proliferative basal cells of the human epidermis (7) as well as corneal endothelium (8). Moreover, MIF was identified as one of the growth factor-induced, delayed early-response genes (9). In support of this finding, we found that MIF mRNA was up-regulated at 3-6 hr after penetrating injury of the cornea, a finding similar to that of other delayed early-response genes (10).

Recently, it was reported that MIF was markedly expressed in primary and metastatic prostate cancer tissues, compared to normal prostatic cells ( 11$)$. This finding suggests that MIF is involved in the proliferation and differentiation of tumor cells. On the basis of this finding, we employed Western and Northern blot analyses and immunohistochemistry, as well as an MIF anti-sense plasmid transfection technique, to investigate whether MIF is involved in tumor cell growth.

\section{Materials and Methods}

\section{Materials}

All of the following materials were obtained from commercial sources. Nitrocellulose membrane filters were purchased from Millipore (Bedford,

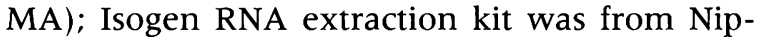
pon Gene (Toyama, Japan); SspI and random primer DNA labeling kit was from Takara (Kyoto, Japan); horseradish peroxidase (HRP)-conju- gated goat anti-rabbit IgG antibody and Micro BCA protein assay kit were from Pierce (Rockford, IL); Konica HRP-1000 immunostaining kit was from Konica (Tokyo, Japan); 3,3'-diaminobenzidine tetrahydrochloride was from Wako (Osaka, Japan); Histofine SAB-PO kit was from Nichirei (Tokyo, Japan); pBK-CMV vector was from Invitrogen (San Diego, CA); G418 (geneticin) was from Sigma (St. Louis, MO); fetal bovine serum (FBS) and RPMI-1640 were from Gibco BRL (Grand Island, NY); human TGF- $\beta$ and rat PDGF (BB) were from R \& D Systems (Minneapolis, MN); human b-FGF was from Progen (Heidelberg, Germany); CellTiter 96 AQ (MTS) assay kit was from Promega (Madison, WI), and Protein A-Sepharose was from Pharmacia (Uppsala, Sweden). All other chemicals used were of analytical grade.

\section{Anti-MIF Antibody}

A polyclonal anti-rat MIF antibody was generated by immunizing New Zealand White rabbits with recombinant rat MIF as previously described (12). The IgG fraction was prepared using Protein A-Sepharose according to the manufacturer's protocol. Since only a single amino acid residue is different between rat and mouse MIFs, the anti-rat MIF immunologically cross-reacted with mouse MIF.

\section{Cell Culture}

The colon 26 cell line, established from BALB/c mice, was a generous gift from Dr. T. Kataoka (Cancer Chemotherapy Center, Tokyo, Japan). Colon 26 cells were cultured in RPMI-1640 medium containing $10 \%$ heat-inactivated FBS at $37^{\circ} \mathrm{C}$ under $5 \% \mathrm{CO}_{2}$, and subcultured twice a week. For all experiments, logarithmically growing cells were used.

\section{Western Blot Analysis}

Western blot analysis was carried out by the method of Towbin et al. (13). In brief, colon 26 cells $\left(5 \times 10^{6}\right.$ cells) were suspended in $200 \mu$ of Tris- $\mathrm{HCl} 50 \mathrm{mM}, \mathrm{pH} 6.8$, containing $\beta$-mercaptoethanol $(1 \%)$, sodium dodecyl sulfate (SDS) $(2 \%)$, glycerol $(20 \%)$, and bromophenol blue $(0.04 \%)$, and boiled at $100^{\circ} \mathrm{C}$ for $5 \mathrm{~min}$. The samples were subjected to SDS-polyacrylamide gel electrophoresis (SDS-PAGE) as previously described (14). The proteins on the gel were electrophoretically transferred onto a nitrocellu- 
lose membrane at $50 \mathrm{~mA}$ for $1 \mathrm{hr}$ using a semidry blot transfer apparatus (Bio-Rad). The nitrocellulose membrane was intensively washed with phosphate-buffered saline (PBS), and incubated with the anti-rat MIF polyclonal antibody (4 $\mu \mathrm{g} / \mathrm{ml} \mathrm{IgG}$ ) at room temperature for $1 \mathrm{hr}$. After washing with PBS containing $0.02 \%$ Tween 20, the membrane was further incubated with HRP-conjugated anti-rabbit IgG $(1 \mu \mathrm{g} / \mathrm{ml})$ for $1 \mathrm{hr}$. After the reaction, proteins were visualized with a Konica HRP-1000 immunostaining kit as recommended in the manufacturer's protocol. Protein concentration was determined with a Micro BCA protein assay reagent kit.

\section{Immunohistochemistry}

Immunohistochemistry for colon 26 cells was performed using a Histofine SAB-PO kit according to the manufacturer's instructions. In brief, the harvested cells were mounted on gelatinized glass slides. They were immersed in methanol containing $0.3 \% \mathrm{H}_{2} \mathrm{O}_{2}$ for 30 min to block endogenous peroxide activity. Following three washing steps in cold PBS containing $10 \%$ sucrose, nonspecific staining was blocked by $10 \%$ normal goat serum in PBS for $10 \mathrm{~min}$, and the tissue specimen was incubated with the anti-rat MIF antibody ( $10 \mu \mathrm{g} / \mathrm{ml}$ PBS) for $30 \mathrm{~min}$ at room temperature. Following three washes in cold PBS containing $10 \%$ sucrose, the specimen was further incubated with biotinylated goat anti-rabbit IgG and avidin-biotin-peroxidase complex for 30 min. After additional washes, the positive staining was visualized by $3,3^{\prime}$-diaminobenzidine tetrahydrochloride containing $0.01 \% \quad \mathrm{H}_{2} \mathrm{O}_{2}$. The cells were counterstained with $1 \%$ methyl green solution.

\section{ELISA}

The MIF concentration was measured by enzyme-linked immunosorbent assay (ELISA) as previously described (15). In brief, the anti-rat MIF antibody $(4 \mu \mathrm{g} / \mathrm{ml})$ was added to each well of a 96-well microtiter plate and left for $1 \mathrm{hr}$ at room temperature. All wells were filled with PBS containing BSA $(1 \%)$ for blocking and left for 1 $\mathrm{hr}$ at room temperature. Samples were added in duplicate to individual wells and incubated for 1 $\mathrm{hr}$ at room temperature. After the plate was washed three times, $50 \mu \mathrm{l}$ of biotin-conjugated anti-rat MIF antibody ( $4 \mu \mathrm{g} / \mathrm{ml} \mathrm{IgG})$ was added to each well. After incubation for $\mathrm{l} \mathrm{hr}$ at room temperature, streptavidin-HRP-conjugated goat anti-rabbit IgG antibody was added to individual wells and they were incubated for $1 \mathrm{hr}$ at room temperature. Fifty microliters of substrate containing o-phenylenediamine and hydrogen peroxide in citrate-phosphate buffer $(\mathrm{pH}$ 5.0) was added to each well. After incubation for $20 \mathrm{~min}$ at room temperature, the reaction was stopped with $4 \mathrm{~N}$ sulfuric acid $(25 \mu \mathrm{l})$. The absorbance at $492 \mathrm{~nm}$ was measured using an ELISA plate reader (Biorad, Model 3550).

\section{Northern Blot Analysis}

Northern blot analysis was carried out as previously described (3). In brief, total RNA was extracted from colon 26 cells $\left(5 \times 10^{6}\right.$ cells $)$ and separated by electrophoresis on agarose gels containing 0.6 M formaldehyde, and blotted onto nylon membrane filters. Hybridization was carried out with the rat MIF CDNA probe, radiolabeled by $\left[\alpha-{ }^{32} \mathrm{P}\right] \mathrm{dCTP}$ using a random primer labeling kit. The hybridization was performed in a solution containing the radiolabeled cDNA probe, $50 \%$ formamide, $0.75 \mathrm{M} \mathrm{NaCl}, 1 \%$ SDS, $20 \mathrm{mM}$ Tris- $\mathrm{HCl}$ (pH 7.5), $2.5 \mathrm{mM}$ EDTA, $0.5 \times$ Denhardt's solution $(1 \times$ Denhardt's; $0.2 \%$ BSA, $0.2 \%$ polyvinylpyrolidone, $0.2 \%$ Ficoll), and $10 \%$ dextran sulfate at $42^{\circ} \mathrm{C}$ for $16 \mathrm{hr}$. After hybridization, the filters were washed with $0.2 \times$ standard saline citrate (SSC) $(1 \times$ SSC; $0.15 \mathrm{M}$ $\mathrm{NaCl}, 0.015 \mathrm{M}$ sodium citrate, $0.1 \%$ SDS) at $65^{\circ} \mathrm{C}$ before autoradiography. After washing, the same filters were also reacted with a radiolabeled murine glyceraldehyde-3-phosphate dehydrogenase (GAPDH) cDNA probe as an internal control. Quantitative analysis was carried out using an MCID Image analyzer (Fuji Film, Tokyo, Japan).

\section{Construction of Anti-sense MIF Plasmid}

The coding region of mouse MIF cDNA was prepared by polymerase chain reaction according to a previous report (16), which was subcloned into the BamHI site of pBK-CMV vector, a eukaryotic expression vector driven by the human cytomegalovirus promoter. Subcloning into the Bam HI restriction site yielded an insert in the anti-sense orientation (pBK-MIFAS) (Fig. 1). The orientation and proof of completeness of the insert were determined by means of restriction enzyme analysis and DNA sequencing using a DNÁ sequencer (ABI, Model 377A). 


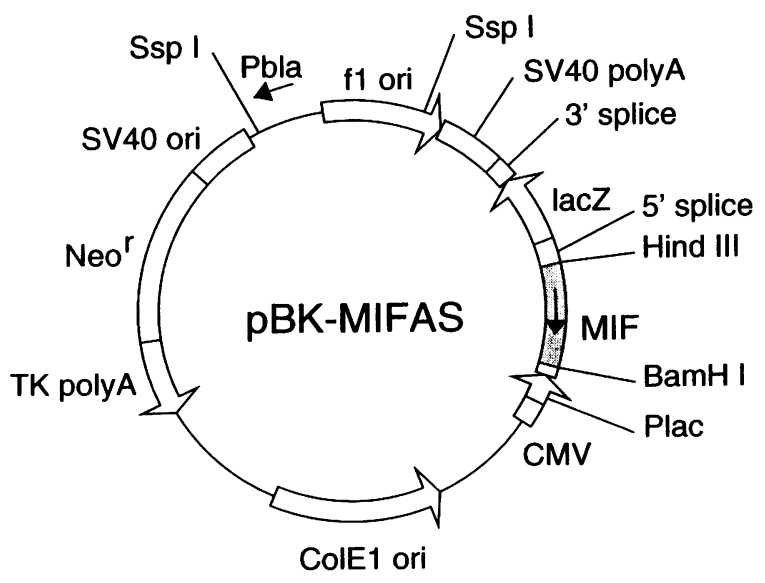

Fig. 1. Construction of the anti-sense MIF plasmid (pBK-MIFAS). The coding region of mouse MIF cDNA was subcloned into the BamHI restriction site of $\mathrm{pBK}-\mathrm{CMV}$ vector, a eukaryotic expression vector driven by the human cytomegalovirus promoter.

\section{Transfection with Anti-sense MIF Plasmid}

Colon 26 cells $\left(2 \times 10^{5}\right.$ cells $)$ suspended in RPMI-1640 without FBS were transfected with either the pBK-MIFAS or the pBK-CMV vector alone linearized with SspI digestion by electroporation using a T820 optimizer (BTX, San Diego, CA) at $200 \mathrm{~V}$ with a single pulse of $10 \mathrm{msec}$. Drug selection was started $24 \mathrm{hr}$ after the transfection by the addition of $\mathrm{G} 418(400 \mu \mathrm{g} / \mathrm{ml})$ to the culture medium containing $10 \%$ FBS. The cells were fed every 3 days with fresh medium for 3 weeks. Then G418-resistant colonies were separately transferred to individual wells of a 48-well plate and colonies were expanded.

\section{Cell Proliferation Assay}

Colon 26 cells with and without anti-sense MIF plasmid transfection were seeded on 96-well culture plates at the initial density of $5 \times 10^{3}$ cells/ well. The MTS assay was performed after incubation for $96 \mathrm{hr}$ according to the manufacturer's protocol. Twenty microliters of $2 \mathrm{mg} / \mathrm{ml}$ MTS solution was added to wells and incubated for 2 $\mathrm{hr}$ at $37^{\circ} \mathrm{C}$. The plates were placed on a shaker for $1 \mathrm{~min}$, and the absorbance was measured with a plate reader read at $490 \mathrm{~nm}$. Each assay was repeated at least three times.

\section{Statistical Analyses}

All data were expressed as mean values and standard deviations. For assessment of effects on cell

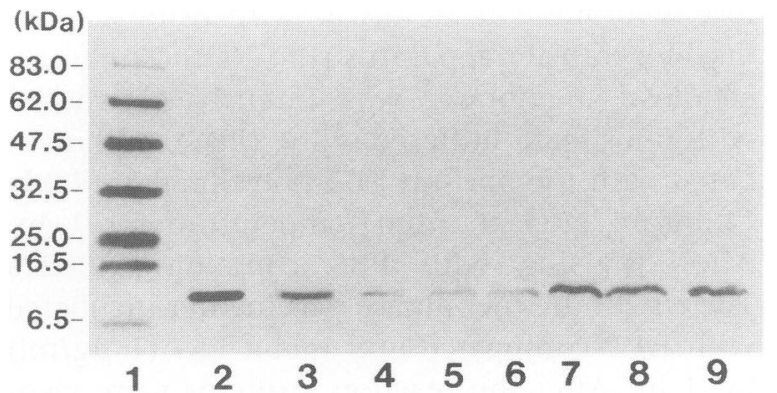

Fig. 2. Expression of MIF protein in colon 26 cells and transfected cells. Western blot analysis was carried out to examine the expression of MIF protein by each cell type. The transfected bands were visualized by a Konica HRP-1000 immunostaining kit. Lane 1, molecular weight markers; lane 2, recombinant rat MIF (100 $\mathrm{ng} / \mathrm{ml})$; lane 3, colon 26 cells $\left(2 \times 10^{5}\right.$ cells); lanes $4-6$, colon 26 cells $\left(2 \times 10^{5}\right.$ cells) transfected with pBK-MIFAS; lanes $7-9$, colon 26 cells $\left(2 \times 10^{5}\right.$ cells $)$ transfected with $\mathrm{pBK}$ vector alone.

growth rate, one-way factorial analysis of variance (ANOVA) was performed, followed by Fisher's protected least-significant difference (PLSD) analysis for multiple comparison. For all statistical analyses, $p>0.05$ was taken as the criterion of significance.

\section{Results}

Identification of MIF Protein

To confirm the expression of MIF protein in the colon 26 cells, Western blot analysis was carried out. The MIF protein band migrated to the corresponding molecular mass of MIF, about 12.5 $\mathrm{kDa}$, which was visualized with a Konica HRP1000 immunostaining kit (Fig. 2, lanes 1-3). In addition, we examined secretion of MIF from colon 26 cells into their culture medium by ELISA. MIF was secreted into the culture medium of colon 26 cells without any treatment. The MIF concentration of culture medium collected at $24 \mathrm{hr}$ culture was $6.1 \pm 1.8 \mathrm{ng} / 10^{4}$ cells. This result showed that MIF protein was expressed constitutively in colon 26 cells.

We also examined the intracellular MIF content of three different pBK-MIFAS transfected cell types by Western blot analysis, which showed significant decreases ( $\sim 0.4$-fold) compared to that of $\mathrm{pBK}$ vector alone (Fig. 2, lanes 4-9). 


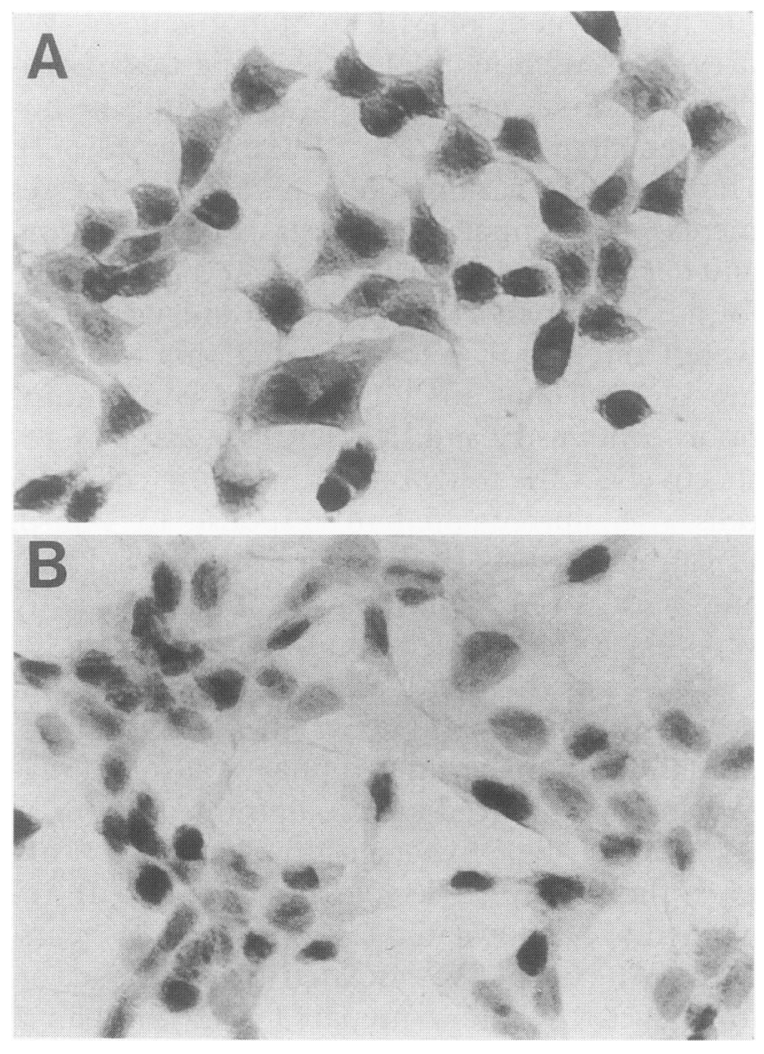

Fig. 3. Immunohistochemistry of colon 26 cells for MIF. (A) Immunohistochemical analysis was carried out using an anti-rat MIF antibody to detect its localization in colon 26 cells. (B) The control cells reacted with the anti-MIF antibody preincubated with an excess amount of rat MIF $(10 \mu \mathrm{g} / \mathrm{ml})$.

\section{Immunohistochemical Analysis}

We performed immunohistochemical analysis using the anti-rat MIF antibody to examine its localization in colon 26 cells. Positive MIF staining was observed largely in the cytosol, and weak positive staining was also observed in the nuclei (Fig. 3A). The control cell sample reacted with the primary antibody premixed with an excess amount of rat MIF (10 $\mu \mathrm{g} / \mathrm{ml})$ did not show any specific positive staining (Fig. 3B).

\section{Influence of Growth Factors on MIF mRNA Expression}

We found that MIF mRNA was increased by the stimulus with TGF- $\beta(0.1-100 \mathrm{ng} / \mathrm{ml})$, PDGF (0.1-100 $\mathrm{ng} / \mathrm{ml})$, or b-FGF $(0.1-100 \mathrm{ng} / \mathrm{ml})$ (Fig. 4). MIF mRNA expression reached the maximum level at $12 \mathrm{hr}$ after stimulation by these growth factors, and remained at a plateau until at least $24 \mathrm{hr}$. Therefore, we examined all dose

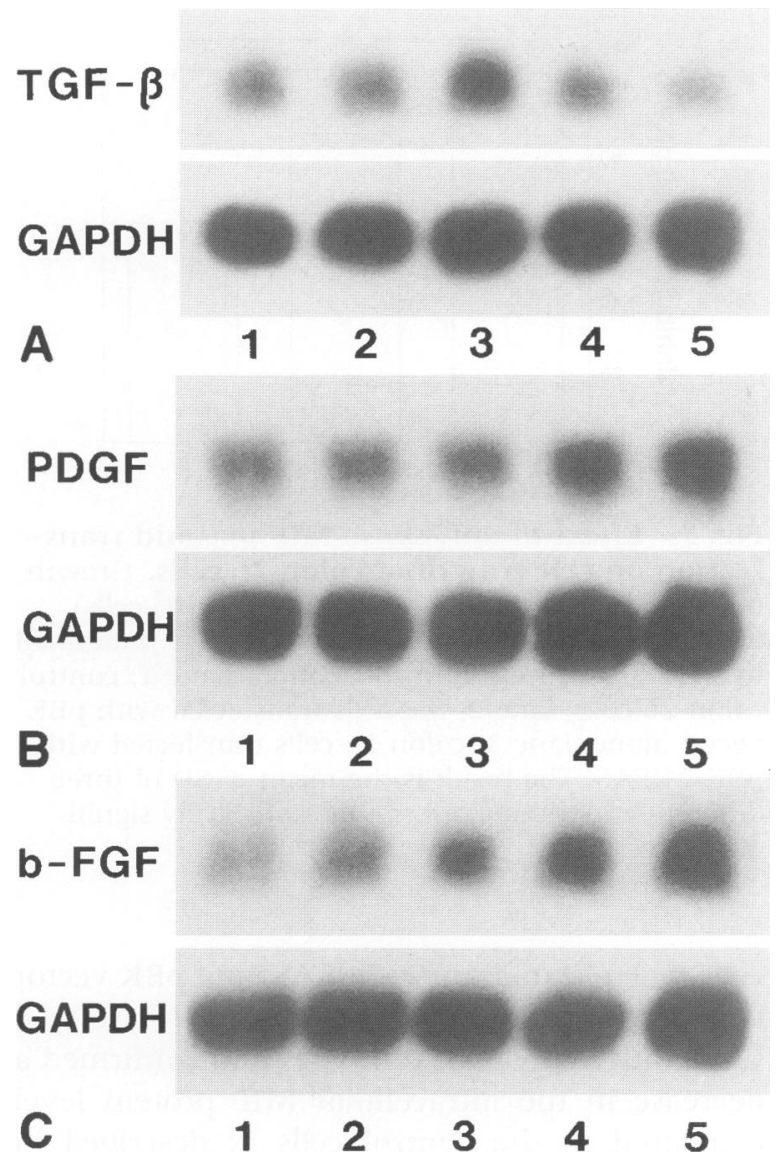

Fig. 4. Northern blot analysis of MIF mRNA expression in colon 26 cells in response to TGF- $\beta$, PDGF, and b-FGF. Total RNA was extracted from cultured cells after $24 \mathrm{hr}$ in RPMI-1640 containing $1 \%$ FBS in the presence of various doses of each growth factor. (A) TGF- $\beta$; lane $1,0 \mathrm{ng} / \mathrm{ml}$; lane $2,0.1 \mathrm{ng} / \mathrm{ml}$; lane $3,1 \mathrm{ng} / \mathrm{ml}$; lane $4,10 \mathrm{ng} / \mathrm{ml}$; lane $5,100 \mathrm{ng} / \mathrm{ml}$. (B) PDGF: lane 1, $0 \mathrm{ng} / \mathrm{ml}$; lane $2,0.1 \mathrm{ng} / \mathrm{ml}$; lane 3,1 $\mathrm{ng} / \mathrm{ml}$; lane $4,10 \mathrm{ng} / \mathrm{ml}$; lane 5, $100 \mathrm{ng} / \mathrm{ml}$. (C) b-FGF: lane $1,0 \mathrm{ng} / \mathrm{ml}$; lane $2,0.1 \mathrm{ng} / \mathrm{ml}$; lane $3,1 \mathrm{ng} / \mathrm{ml}$; lane $4,10 \mathrm{ng} / \mathrm{ml}$; lane $5,100 \mathrm{ng} / \mathrm{ml}$. The profile of GAPDH is shown at the bottom of each lane.

dependency at $24 \mathrm{hr}$ after stimulation. TGF- $\beta$ up-regulated the expression to the maximum level with the dose of $1 \mathrm{ng} / \mathrm{ml}$ (1.4-fold), but the expression level was gradually decreased by more than $10 \mathrm{ng} / \mathrm{ml}$. PDGF and b-FGF induced the up-regulation of MIF mRNA in a dose-dependent manner, and increased the level 1.7fold and 1.6-fold with a dose of $100 \mathrm{ng} / \mathrm{ml}$ concentration, respectively.

\section{Effect of Anti-sense MIF Plasmid Transfection on Cell Proliferation}

We examined the effect of anti-sense MIF plasmid transfection on cell proliferation of colon 26 


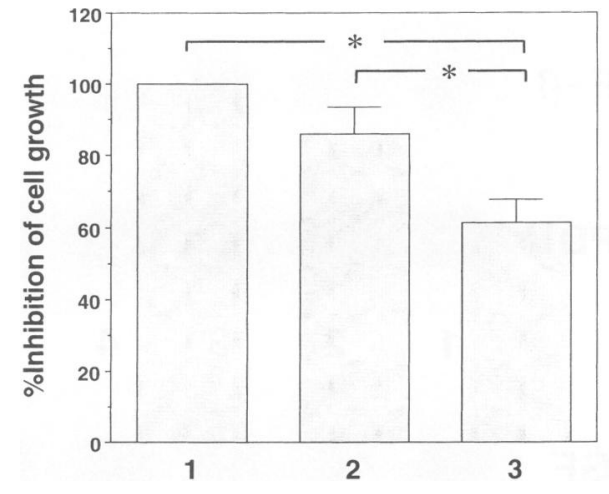

Fig. 5. Effect of anti-sense MIF plasmid transfection on cell growth of colon 26 cells. Growth of colon 26 cells (initial cell count, $5 \times 10^{3}$ cells) transfected with anti-sense MIF cDNA was examined by MTS assay after $96 \mathrm{hr}$ incubation. Lane l, control colon 26 cells; lane 2 , the cells transfected with pBK vector alone; lane 3 , colon 26 cells transfected with pBK-MIFAS. The result is the mean \pm SD of three different experiments $(n=9)$; *statistically significant $(p<0.01)$.

cells. The plasmids, pBK-MIFAS, and pBK vector were linearized with SspI before use. We isolated three different clonal cell types and confirmed a decrease in the intracellular MIF protein level compared to the control cells as described in Figure 2 . The control cells were prepared by electroporation without any plasmid vector. The cell growth rate was examined by MTS assay for colon 26 cells transfected with either the pBKMIFAS or pBK vector alone. The proliferation rate of the transfected colon 26 cells with pBKMIFAS was markedly suppressed (61.1 \pm $10.5 \%$ ) compared to the control cells (Fig. 5). In the cells transfected with the vector alone, it was slightly decreased $(85.8 \pm 12.3 \%)$. From these results, it was concluded that the intracellular content of MIF might be a critical component of promoting cell growth.

\section{Discussion}

Meyer-Siegler et al. identified enhanced MIF mRNA levels in prostatic adenocarcinoma and its metastatic tumors in comparison with normal prostatic tissues by means of the differential display-polymerase chain reaction technique (11). Consistent with this finding, we identified higher expression of MIF in human primary and metastatic colon cancer tissues than in normal colonic mucosal tissues (unpublished observation). These observations prompted us to investigate the involvement of MIF in tumorigenesis. We previously reported biological properties of proliferation, invasion, and metastasis of murine undifferentiated carcinoma cell line colon 26 (17). The metastatic variant of colon 26 cells possesses increased potential for metastasis and invasion, and has been well characterized. Accordingly, we found at first that MIF protein and its mRNA were expressed in colon 26 carcinoma cells, using Western blot analysis together with immunohistochemistry and Northern blot analysis, respectively. MIF mRNA expression of colon 26 cells was up-regulated in response to TGF- $\beta$, PDGF, and b-FGF. Moreover, we showed that anti-sense MIF plasmid transfection significantly suppressed the proliferation of colon 26 cells.

MIF was the first lymphokine discovered in the culture medium of activated $\mathrm{T}$ cells, and this protein accumulated macrophages at inflammatory loci and induced various immune responses, e.g., delayed-type hypersensitivity $(18,19)$. However, the precise molecular function of MIF remained to be elucidated for more than 25 years. Since MIF cDNA was isolated by Weiser et al. from a cDNA library prepared using human $\mathrm{T}$ cells (20), previously unrecognized properties of this protein have been discovered. Bernhagen et al. demonstrated that MIF is the major secretory protein released by anterior pituitary cells in response to lipopolysaccharide, and an anti-MIF antibody fully prevented lethality from endotoxin shock (21). Moreover, MIF was determined to be essential for $\mathrm{T}$ cell activation (22). It should also be noted that MIF secreted from anterior pituitary cells can counterregulate the effect of glucocorticoids (23). MIF is also expressed in a variety of organs. Macrophages, in particular, are the major source of this protein (2).

There are several reports (6-9) suggesting the possible involvement of MIF in cell growth; however, there has been no clear evidence demonstrating a direct link of MIF with cell growth. In this study, we found that tumor proliferation was significantly suppressed by anti-sense MIF plasmid transfection as described above. This fact strongly indicated that intracellular MIF might be profoundly involved in the mechanism of tumor cell growth. Although cloned anti-sense transfected cells showed a decreased proliferation rate until 4-6 weeks after isolation, the proliferation rate was gradually restored to the control level or higher in accordance with the duration of culture, in spite of the fact that the cells were still resistant to G418. To further in- 
vestigate this phenomenon, we carried out Northern blot analysis of these long-term cultured clonal cells. The result revealed that the level of MIF mRNA of these cells was higher than that of the control (data not shown). In addition, during the process of cloning transfected cells, we observed microscopically that highly and effectively transfected cells appeared to be remarkably transformed, with vacuoles in the cytosol, and never divided. On the basis of these observations, it is conceivable that MIF is essential for cell growth.

Growth factors and cytokines released from macrophages appear to be important for the response of the host with cancer. For example, TGF- $\beta$ is associated with progression of tumorigenicity and invasion, and increase of TGF- $\beta$ is found in human colon cancer correlated with disease progression to metastasis (24). PDGF is elevated in good correlation with tumor size, and the protein released from colon carcinoma cells stimulates the growth of NIH3T3 cells in a paracrine manner (25). Moreover, b-FGF contributes to cancer cell proliferation, as the mRNA is overexpressed in correlation with progression of cancer cells (26). As demonstrated in this study, MIF mRNA expression of colon 26 cells was significantly induced by these growth factors. These data suggest that MIF is involved in the mechanism of tumor cell growth in concert with these growth factors. We found that the growth rate of colon 26 cells was minimally affected by the addition of recombinant MIF to the culture medium. Therefore, it is speculated that an increase in intracellular MIF content rather than extracellular MIF would be critical for cell growth. This finding is consistent with the results of MIF antisense plasmid transfection. Thus, we hypothesized that growth factors released from the tumor cells as well as tumor-associated macrophages could induce tumor cell growth via elevation of the intracellular MIF content.

Finally, we presented evidence that MIF could be an important protein for promotion of tumor growth, possibly in concert with other growth factors. The current results indicate that it may be possible to establish a new therapeutic approach using an anti-MIF antibody and antisense MIF plasmid transfection. To verify this possibility, we are currently investigating the effect of anti-MIF antibody on tumor cell proliferation and tumor metastasis in vivo.

\section{Acknowledgments}

We are grateful to M. Suzuki and T. Kuriyama for their technical assistance, and to Y. Mizue of Sapporo Immunodiagnostic Laboratory for preparation of the anti-MIF antibody.

\section{References}

1. Anzano MA, Rieman D, Prichett W, Bowen-Pope DF, Grieg R. (1989) Growth factor production by human colon carcinoma cell lines. Cancer Res. 49: 2898-2904.

2. Calandra T, Bernhagen J, Mitchell RA, Mitchell J, Bucala R. (1994) The macrophage is an important and previously unrecognized source of macrophage migration inhibitory factor. J. Exp. Med. 179: 1895-1902.

3. Sakai M, Nishihira J, Hibiya Y, Koyama Y, Nishi S. (1994) Glutathione binding rat liver $13 \mathrm{~K}$ protein is the homologue of the macrophage migration inhibitory factor. Biochem. Mol. Biol. Int. 33: 439446.

4. Bacher M, Meinhardt A, Lan HY, et al. (1997) Macrophage migration inhibitory factor expression in experimentally induced endotoxemia. Am. J. Pathol. 150: 235-246.

5. Bucala R. (1996) MIF rediscovered: cytokine, pituitary hormone, and glucocorticoid-induced regulator of the immune response. FASEB J. 10: 1607-1613.

6. Wistow GJ, Shaughenessy MP, Lee DC, Hodin J, Zelenka PS. (1993) A macrophage migration inhibitory factor is expressed in the differentiating cells of the eye lens. Proc. Natl. Acad. Sci. U.S.A. 90: 1272-1275.

7. Shimizu T, Ohkawara A, Nishihira J, Sakamoto W. (1996) Identification of macrophage migration inhibitory factor (MIF) in human skin and its immunohistochemical localization. FEBS Lett. 381: 199-202.

8. Matsuda A, Tagawa Y, Matsuda H, Nishihira J. (1996) Identification and immunohistochemical localization of macrophage migration inhibitory factor in human cornea. FEBS Lett. 385: 225-228.

9. Lanahan A, Williams JB, Sanders LK, Nathans D. (1992) Growth factor-induced delayed early response genes. Mol. Cell. Biol. 12: 3919-3929.

10. Matsuda A, Tagawa Y, Matsuda H, Nishihira J. (1997) Expression of macrophage migration inhibitory factor in rat corneal wound healing. Invest. Ophthalmol. Vis. Sci. 38: 1555-1562.

11. Meyer-Siegler K, Hudson PB. (1996) Enhanced expression of macrophage migration inhibitory factor in prostatic adenocarcinoma metastases. Urology 48: 448-452.

12. Nishihira J, Kuriyama T, Sakai M, Nishi S, Ohki S, Hikichi K. (1995) The structure and physicochemical properties of rat liver macrophage migration 
inhibitory factor. Biochim. Biophys. Acta. 1247: 159-162.

13. Towbin H, Staehelin T, Gordon J. (1979) Electrophoretic transfer of protein from polyacrylamide gels to nitrocellulose sheets: procedure and some applications. Proc. Natl. Acad. Sci. U.S.A. 76: 43504354.

14. Schagger H, Von Jagow G. (1987) Tricine-sodium dodecyl sulfate-polyacrylamide gel electrophoresis for the separation of proteins in the range from 1 to $100 \mathrm{kDa}$. Anal. Biochem. 166: 368-379.

15. Onodera S, Suzuki K, Matsuno T, Kaneda K, Kuriyama T, Nishihira J. (1997) Macrophage migration inhibitory factor induces phagocytosis of foreign particles by macrophages in autocrine and paracrine fashion. Immunology 92: 131-137.

16. Mitchell R, Bacher M, Bernhagen J, Pushkarshaya T, Seldin MF, Bucala R. (1995) Cloning and characterization of the gene for mouse macrophage migration inhibitory factor (MIF). J. Immunol. 154: 3863-3870.

17. Ohnishi Y, Sakamoto T, Fujii H, et al. (1997) Characterization of a liver metastatic variant of murine colon26 carcinoma cells. Tumor Biol. 18: 113-122.

18. Bloom BR, Bennett B. (1966) Mechanism of a reaction in vitro associated with delayed-type hypersensitivity. Science 153: 80-82.

19. David JR. (1966) Delayed hypersensitivity in vitro: its mediation by cell free substances forms by lymphoid cell-antigen interaction. Proc. Natl. Acad. Sci. U.S.A. 56: 72-77.
20. Weiser WY, Temple PA, Witek-Giannotti JS, Remold HG, Clark SC, David JR. (1989) Molecular cloning of a cDNA encoding a human macrophage migration inhibitory factor. Proc. Natl. Acad. Sci. U.S.A. 86: 7522-7526.

21. Bernhagen J, Calandra T, Mitchel RA, et al. (1993) MIF is the pituitary-derived cytokine that potentiates lethal endotoxaemia. Nature 365: $756-759$.

22. Bacher M, Metz CN, Calandra T, et al. (1996) An essential regulatory role for macrophage migration inhibitory factor in T-cell activation. Proc. Natl. Acad. Sci. U.S.A. 93: 7849-7854.

23. Calandra T, Bernhagen J, Mets CN, et al. (1995) MIF as a glucocorticoid-induced modulator of cytokine production. Nature 377: 68-71.

24. Huang F, Newman E, Theodorescu D, Derbel RS, Friedman E. (1995) Transforming growth factor beta 1 (TGF beta 1 ) is an autocrine positive regulator of colon carcinoma U9 cells in vivo as shown by transfection of a TGF beta 1 antisense expression plasmid. Cell Growth Differ. 6: 1635-3642.

25. Hsu S, Huang F, Freiedman E. (1995) Plateletderived growth factor- $B$ increases colon cancer cell growth in vivo by a paracrine effect. J. Cell. Physiol. 165: 239-245.

26. Yamanaka Y, Friess H, Buchler M, et al. (1993) Overexpression of acidic and basic fibroblast growth factor in human pancreatic cancer correlates with advanced tumor stage. Cancer Res. 53: 5289-5296. 